\title{
TRAUMA HEALING DAN EDUKASI PERLINDUNGAN ANAK PASCA GEMPA BAGI ANAK-ANAK DI DESA WAAI
}

\author{
Anna Maria Salamor ${ }^{1}$, Yonna Beatrix Salamor ${ }^{2}$, Erwin Ubwarin ${ }^{3}$ \\ ${ }^{1,2,3)}$ Program Studi Ilmu Hukum, Fakultas Hukum, Universitas Pattimura \\ e-mail: annamariasalamor@gmail.com
}

\begin{abstract}
Abstrak
Bencana gempa bumi yang menimpa Desa Waai Kecamatan Salahutu, Pulau Ambon, Kabupaten Maluku Tengah mengakibatkan banyak kerugian baik secara fisik maupun non fisik. Kerugian berupa non fisik meliputi adanya trauma yang dimiliki terutama pada anak-anak. Pasca gempa sebagian dari korban yang selamat dan luka mengalami trauma sehingga terganggu kondisi mentalnya dan psikologisnya. Trauma ini tidak bisa dibiarkan berlarut-larut terlalu lama karena akan berdampak pada kondisi kehidupan anak tersebut. Tujuan pengabdian ini dilakukan memberi dukungan dan pendampingan kepada anak-anak tentang trauma healing sebagai wujud tanggap bencana untuk menggurangi gangguan psikologis yang sedang dialami korban gempa bumi. Metode yang digunakan dalam pengabdian masyarakat ini yaitu penyuluhan yang diselingi dengan terapi bermain (play therapy) dan self motivation yang syarat akan muatan edukasi. Adapun hasil kegiatan yang dilakukan yaitu penyembuhan trauma pada anak-anak pasca gempa membutuhkan proses berkesinambungan, pendekatan yang dapat kita dilakukan dengan cara bermain, menari dan bercerita bersama anak-anak dilokasi pengungsian. Tujuan dari kegiatan ini untuk menghilangkan rasa takut dan melupakan kesedihan atas trauma yang dialami.
\end{abstract}

Kata Kunci: Trauma Healing, Anak-anak, Waai

\begin{abstract}
The earthquake that struck Waai Village Salahutu Subdistrict, Ambon Island, Central Maluku left a loss, both physically and non-physically. Losses in the form of non-physical include the trauma of mainly children. After the earthquakes, some of the survivors and injuries were trauma so that their mental and psychological conditions were disturbed. This trauma cannot be allowed to drag on too long because it will adversely affect the lives of the victims children. The purpose of this service is to provide support and assistance to children about trauma healing as a form of disaster response to help with the psychological disorders that earthquake victims are experiencing. The methods used in community service are counseling interspersed with play therapy and self motivation that requirements educational content. As for the results of the activities carried out, namely trauma healing in post-earthquake children requires a continuous process, an approach that we can do by playing, dancing and telling stories with children in refugee camps. The purpose of this activity is to get rid of fear and forget sadness over the trauma experienced.
\end{abstract}

Keywords: Trauma Healing, Kids, Waai

\section{PENDAHULUAN}

Bencana merupakan sebuah kekuasaan Tuhan, yaitu kejadian alamiah yang bisa kapan pun terjadi. Undang -Undang No 24 Tahun 2007 menjelaskan bahwa bencana ialah sebuah rangkaian kejadian yang dapat mengganggu dan mengancam penghidupan dan kehidupan masyarakat sekitar yang disebabkan oleh faktor alam, non alam atau faktor manusia yang dapat menelan korban jiwa manusia, rusaknya lingkungan, kehilangan harta benda, dan dampak pada psikologis. Indonesia merupakan salah satu negara yang paling rentan terkena bencana. Baik itu bencana alam, non alam ataupun kerusakan yang dilakukan oleh manusia. Beberapa bencana yang sering terjadi ialah gempa bumi, gunung meletus, tsunami, tanah longsor, banjir bandang, kekeringan, kebakaran, angin puting beliung, badai, dan sebagainya. 
Waai sebagai salah satu desa yang berada di Kecamatan Salahutu, Pulau Ambon, Kabupaten Maluku Tengah dengan penduduk lebih dari 1.000 jiwa, menyimpan berbagai trauma saat terjadi saat gempa berkekuatan 6,5 Mw. Gempa dengan kekuatan 6,5 Mw pada tanggal 26 September 2019 menghantam Provinsi Maluku dengan pusat gempa berjarak $42 \mathrm{~km}$ Timur Laut Kota Ambon, Maluku dengan kedalaman $10 \mathrm{~km}$ (Wikipedia). Gempa tersebut tidak berpotensi tsunami namun menyebabkan puluhan rumah rusak di beberapa titik salah satunya di Desa Waai dan menimbulkan korban jiwa. Akibatnya banyak warga mengungsi karena rumahnya roboh dan takut dengan gempa susulan yang masih terjadi serta mereka mengalami trauma pasca bencana dengan peningkatan yang cukup drastis.

Trauma adalah respon emosional terhadap kejadian yang buruk dan tindakan tidak menyenangkan seperti kecelakaan, kejahatan maupun bencana alam. Trauma berhubungan dengan keadaan psikologis seseorang. Esther Giller, Sidran Institute (2018) mendeskripsikan "A traumatic event or situation creates psychological trauma when it overwhelms the individual's ability to cope, and leave that person fearing death, annihilation, mutilation, or psychosis". Trauma psikologis merupakan pengalaman individu atau kondisi yang sedang dialami, dimana individu tersebut merasa kewalahan secara emosi, kognitif, dan fisik sehingga kemampuan untuk mengatasi kondisinya terganggu.

Bencana menurut United Nation Development Program (UNDP) adalah suatu kejadian ekstrem dalam lingkungan alam atau manusia yang berakibat merugikan dan mempengaruhi kehidupan manusia, harta benda atau aktivitas sampai pada tingkat yang menimbulkan bencana. (Soehatman Ramli: 2014) Penting untuk ditekankan, bahwa setiap korban gempa yang mengalami trauma dan krisis emosi seringkali mengalami disorientasi spiritual. Dalam keadaan yang serba kekurangan, banyak diantara korban gempa menggantungkan hidup kepada orang-orang atau lembaga yang memberi bantuan materi. Sudah seharusnya dalam gejala spiritual, korban gempa harus tetap bergantung pada agama dan Tuhan yang telah menurunkan bencana. Agar pemulihan psikologis dan trauma pasca gempa menjadi lebih mudah dilakukan.

Ditengah rasa kekhawatiran dan ketakutan yang melanda akan menjadi sangat penting bagi anak-anak untuk mendapatkan pelayanan pemulihan trauma yang disebut trauma healing. Dukungan psikologis setelah terjadi bencana alam seperti gempa bumi sangat diperlukan untuk mengurangi tingkat trauma terhadap masyarakat yang terdampak bencana.

Trauma healing adalah accepting, sebuah penerimaan. Kegiatan trauma healing yang dilakukan oleh Dosen Bagian Pidana Fakultas Hukum Universitas Pattimura merupakan bentuk dukungan psikologis mental healing yang diperuntukkan bagi korban gempa di Desa Waai. Hal tersebut juga merupakan salah satu rangkaian kegiatan pengabdian masyarakat yang bertujuan untuk menangani masalah psikologis seperti stress, ketakutan, dan trauma pasca bencana. Pemulihan trauma pada anak-anak memerlukan dukungan keluarga dan orang dewasa di sekitarnya.

Trauma healing yang dilaksanakan menawarkan kegiatan permainan sebagai bentuk terapi kepada anak-anak. Terapi bermain (play therapy) dapat mengalihkan fokus anak dari situasi yang mencekam maupun mengkhawatirkan. Bermain setidaknya dapat mempersiapkan mental anak untuk menerima situasi yang dihadapi sekarang. Sehingga bila digunakan pada situasi dan kondisi yang tepat dapat bermakna sebagai kegiatan fisik sekaligus sebagai terapi (Endah Nawangsih, 2014: 164). Penanganan dampak psikologis terhadap korban bencana gempa bumi ditempuh dengan cara memberikan dukungan psikososial, sebagai bentuk pemulihan trauma.

\section{METODE}

Kegiatan pengabdian masyarakat yang dilaksanakan di Desa Waai dilakukan dengan menggunakan metode pendidikan masyarakat. Salah satu bentuk metode pendidikan masyarakat yang digunakan antara lain dengan melakukan penyuluhan, permainan. Penyuluhan hukum dilakukan setelah sebelumnya dilakukan identifikasi permasalahan yang terjadi di Desa Waai. Penyuluhan ini diharapkan salah satu wujud bentuk Pengabdian Masyarakat Dosen dan Mahasiswa Fakultas Hukum Universitas Pattimura Bagian Hukum Pidana, memberikan pemahaman kepada masyarakat Desa Waai terkhusus kepada Anak- 
anak tentang Perlindungan Anak. Pengabdian Masyarakat yang bertemakan trauma healing dan edukasi Perlindungan anak ini diharapkan memberikan sedikit pencerahan kepada anak-anak Desa Waai mengenai Posisi anak sebagai generasi penerus bangsa dimana negara memiliki kewajiban untuk melindungi Hak-hak mereka.

\section{HASIL DAN PEMBAHASAN}

Kegiatan trauma healing merupakan salah satu dari rangkaian kegiatan pengabdian masyarakat. Trauma healing yang dilakukan bertujuan untuk menurunkan tingkat kecemasan dan mengembalikan kondisi emosional anak-anak pasca bencana gempa bumi dengan berbagai macam permainan yang dilakukan secara individu maupun kelompok.

Dunia anak merupakan dunia yang hampir keseluruhannya berupa tindakan dan aktifitas. Bermain merupakan bahasa anak, anak akan memiliki imajinasi yang sangat luas dengan dunia bermainnya sendiri. Karenanya bermain menjadi salah satu metode yang cukup baik dalam mengatasi kecemasan pada anak. Beberapa studi dan riset yang berkenaan dengan peran dan fungsi permainan bagi proses perkembangan anak banyak ditemukan.

Trauma pada dasarnya menurut kamus Psikologi berarti sakit, atau shock yang seringkali berupa fisik atau struktural maupun juga mental dalam bentuk shock emosi yang menghasilkan gangguan lebih kurang tentang ketahanan fungsi-fungsi mental (Drever, 1988). Sedangkan healing secara bahasa memiliki arti penyembuhan (Shadily, 1992). Sehingga dapat disimpulkan bahwa Trauma Healing merupakan satu proses pemberian bantuan berupa penyembuhan untuk mengatasi gangguan psikologis seperti kecemasan, panik, dan gangguan lainnya karena lemahnya ketahanan fungsi-fungsi mental yang dimiliki individu korban bencana alam tersebut. Trauma Healing merupakan salah satu kebutuhan utama khususnya bagi korban bencana, dengan terapi trauma healing korban diharapkan dapat berangsur pulih dari trauma yang dialami dalam hidupnya. Karena trauma merupakan sebuah kejadian emosional dan fisik yang dapat dikatakan serius karena mengakibatkan kerusakan substansial terhadap fisik dan psikologis seseorang dalam rentangan waktu yang relatif lama (Weaver, 2003). Trauma dapat menyebabkan kondisi emosional yang dapat berkembang dikarenakan adanya sebuah peristiwa yang kurang berkenan, menyedihkan, menyakitkan, menakutkan, mencemaskan dan menjengkelakan.

Menurut psikolog anak dan keluarga, Ratih Zulhaqqi, trauma healing bertujuan untuk mengantisipasi Post-Traumatic Syndrome Disorder(PTSD). PTSD adalah gangguan stres pascatrauma. Trauma healing untuk anak, kata Ratih, cenderung agak sulit sebab anak seringkali sulit bercerita perihal kecemasannya seperti orang dewasa. Ia berkata, bermain menjadi metode trauma healing yang tepat buat anak "(Kalau bermain), mereka enggak merasa sedang diobati, enggak merasakan situasi yang mencekam. Dan yang mendampingi tidak boleh selalu mengungkit cerita (tentang gempa)," katanya saat dihubungi oleh CNNIndonesia.com

Gangguan trauma paska stres atau yang dikenal juga sebagai Post Traumatic Stress Disorder (PTSD) adalah sebuah kondisi gangguan kesehatan mental akibat peristiwa yang mengerikan, seperti kecelakaan, perang, ataupun kejadian bencana alam (gempa bumi, tsunami, longsor dan lainnya). Dampak dari gangguan trauma itu sendiri tentu bervariasi, dari yang ringan sampai yang berat. Berikut beberapa diantaranya: Selalu merasa cemas dan sangat mengganggu, Terbayang-bayang dengan peristiwa bencana, Mimpi buruk yang menyebabkan kesulitan tidur, Kondisi fisik penderita menjadi siaga ketika mereka mengingat ataupun memikirkan trauma yang dialami.

Gejala psikis seperti demikian tidak bisa dibiarkan berlarut-larut. Para korban harus dibantu agar pulih kondisi psikologisnya dari pengalaman traumatis melalui pemulihan trauma (trauma healing). Gangguan PTSD pada korban bencana muncul setelah 1 bulan, sedangkan gangguan trauma yang muncul kurang dari 1 bulan disebut Acute Stress Disorder (ASD). Biasanya korban yang mengalami ASD dapat 
pulih kembali dari gangguan trauma sehingga hanya memerlukan dukungan psikososial. Sedangkan Gangguan PTSD memerlukan penanganan khusus, seperti terapi psikis dengan intervensi khusus dan jika sangat mengganggu dapat dipertimbangkan pemberian obat-obatan. Lalu bila kita didekat mereka, apa saja kira-kira yang bisa kita lakukan untuk memulihkan kondisi tersebut.

1. Meminimalkan paparan media yang memberitakan tentang bencana atau peristiwa tersebut.

2. Menghindarkan mereka dari tempat-tempat dimana kejadian mengerikan itu berlangsung.

3. Memberikan dukungan, kita perlu menunjukkan bahwa kita peduli dan berempati terhadap kondisi korban.

4. Memberikan donasi dalam bentuk pangan, sandang, dan papan.

5. Mengajak para korban untuk bermain dan bersenda gurau, hal ini dapat meringankan tekanan traumatis yang dialami korban.

6. Melakukan kegiatan bersama-sama seperti memasak di dapur umum.

7. Menjadi pendengar cerita para korban, bila mereka siap menceritakan musibah yang dialaminya

Secara moral, dukungan psikososial ditujukan untuk melepaskan korban dari perasaan ketakutan yang dialaminya, bukannya bertujuan untuk melupakan peristiwa pahit tersebut. Dan kegiatan yang dilakukan bersama-sama memberikan efek psikologis yang kuat kepada korban yang menandakan bahwa mereka tidak sendirian dalam menghadapi peristiwa ini. Selain itu edukasi seputar informasi bencana atau informasi bantuan pun menjadi hal yang penting dan dapat disampaikan kepada korban sehingga apabila bencana susulan terjadi para korban mengerti apa yang harus dilakukan.

Kondisi psikologis seseorang setelah mengalami trauma dapat kembali pulih atau normal. Tentunya pemulihan kondisi psikologis seseorang tergantung dari bagaimana mereka mampu menghadapi situasi sulit serta ketersediaan sumber-sumber daya lokal yang dapat menunjang proses pemulihan trauma. Namun, tidak dipungkiri bahwa gangguan trauma dapat menetap dan berkepanjangan sehingga memerlukan penanganan yang lebih lanjut dan bersifat holistik.

Kegiatan trauma healing dan edukasi perlindungan anak pasca gempa di Desa Waai dapat dilakukan dengan metode pemulihan trauma berdasarkan Psychology Today (2014) dalam Khalika (2018) terdiri dari pemberian obat dan terapi psikis. Terapi psikis dibedakan untuk anak-anak dan orang dewasa. Bentuk terapi untuk orang dewasa adalah bimbingan konseling. Trauma healing pada orang dewasa biasanya lebih mudah dilakukan, karena mereka bisa dengan mudah mengekspresikan apa yang dirasakannya secara verbal. Sementara terapi psikis untuk anak-anak adalah play therapy dengan memanfaatkan media permainan dan dance therapy berfungsi untuk mengekspresikan emosi anak-anak.

Wujud dari terapi bermain (play therapy) adalah bernyanyi, menari, bercerita yang dikombinasikan dengan materi tentang perlindungan anak. Hal ini penting dilakukan dengan tujuan untuk menjaga mental anak agar tetap stabil. Kegiatan play therapy ini dipandu oleh beberapa dosen dan mahasiswa dari Fakultas Hukum. Pada awalnya anak-anak SMTPI Waai terlihat malu dan tidak berani ketika diminta untuk bernyanyi dan menari mengikuti gerakan yang diperagakan oleh dosen dan mahasiswa fakultas hukum. Setelah diyakinkan oleh dosen, pengasuh dan mahasiswa anak-anak SMTPI Waai terlihat antusias mengikuti apa yang diinstruksikan. Anak-anak tampak senang, bahagia seolah-olah beban dan rasa takut yang dialami hilang sejenak dari pikiran mereka. Bermain menjadi salah satu cara trauma healing yang dapat dilakukan untuk mencegah anak-anak dari trauma berkepanjangan. Oleh karena itu, bermain dapat digunakan sebagai media psikoterapi yang kemudian disebut dengan terapi bermain. Bagi anak, bermain adalah suatu kebutuhan yang sudah ada dengan sendirinya (inherent).

Setelah itu permainan dilanjutkan dengan materi tentang perlindungan anak yang dibawahkan oleh seorang dosen. Materi tentang pengertian perlindungan terhadap anak, undang-undang tentang perlindungan anak, serta sanksi bagi orang tua yang melakukan kekerasan terhadap anak. Kegiatan pengabdian kepada anak-anak di tempat pengungsian Desa Waai ditutup dengan memberikan bantuan kepada SMTPI Waai dengan harapan anak-anak tersebut dapat melupakan kesedihan atas trauma yang sedang dialami. 


\section{SIMPULAN}

Trauma healing dan edukasi perlindungan anak pasca gempa diperlukan penanganan khusus untuk menghilangkan trauma dan ketakutan sebagai efek psikis setelah terjadi bencana terutama kepada anakanak. Penyembuhan trauma pada anak-anak pasca kejadian bencana yang telah dialami membutuhkan proses yang lama dan berkesinambungan. Walaupun kegiatan ini dilaksanakan dalam waktu yang terbatas tapi pesan yang disampaikan mampu diterima baik oleh anak-anak agar dapat mengembalikan senyuman mereka dalam menghadapi kehidupan yang ideal kedepannya

\section{SARAN}

Kami berharap dengan adanya penyuluhan, permainan bagi anak-anak di Desa Waai dapat menghilangkan trauma dan memberikan ruang bagi mereka untuk menyampaikan rasa takut yang dialami serta adanya pengawasan dari orang tua.

\section{UCAPAN TERIMA KASIH}

Pemerintahan Desa Waai

Pengasuh dan Anak-anak SMTPI jemaat GPM Waai

Fakultas Hukum Universitas Pattimura

\section{DAFTAR PUSTAKA}

Esther Giller. Sidran Institute. (2018). What Is Psychological Trauma? (Oniline), (https://www.sidran.org/resources/forsurvivors-and-loved-ones/what-ispsychological-trauma/), diakses pada tanggal 12 Oktober 2020.

Endah Nawangsih.(2014). Play Therapy Untuk Anak-anak Korban Bencana Alam Yang Mengalami Trauma (Post Traumatic Stress Disorder/PTSD). Psympathic, Jurnal Ilmiah Psikologi, 1(2), 164-178. https://www.cnnindonesia.com/gaya-hidup/20180806134142-277-319896/terapi-bermain-trauma-healinguntuk-anak-pascagempa, Diakses tanggal 12 Oktober 2020

Shadily, J. M. (1992). Kamus Inggris-Indonesia an English-Indonesian Dictionary. Jakarta: Gramedia. Weaver, A. F. (2003). Counseling Survivors of Traumatic Events: A handbook for pastors and other helping professional. Nashville: Abingdon Press. 